\title{
PENGARUH KOMPETENSI SUMBER DAYA MANUSIA DAN PENGGUNAAN ANGGARAN TERHADAP EFEKTIVITAS PENERAPAN ANGGARAN BERBASIS KINERJA PADA DINAS PERINDUSTRIAN DAN PERDAGANGAN DAERAH PROVINSI SULAWESI UTARA
}

\author{
Melisa Sumampow ${ }^{1}$, Jantje Tinangon ${ }^{2}$, Steven Tangkuman ${ }^{3}$ \\ ${ }^{12}$ Fakultas Ekonomi dan Bisnis . Jurusan Akuntansi. Universitas Sam Ratulangi, Jl. Kampus Bahu, Manado, \\ 95115, Indonesia \\ E-mail :melisasumampow@gmail.com
}

\begin{abstract}
Performance-based budgeting is a system of preparation and management of local budgets that are oriented towards the achievement of results or performance. Performance-based budgets are influenced by the competence of human resources, rewards, and budget usage. This study aims to determine the influence of competence of human resources, rewards, and budget usage on the effectiveness of performance-based budgeting. The population of this research is 61 staff of civil servants in North Sulawesi Industry and Trade Service Office. This research uses multiple linear regression analysis method with data management using SPSS 22 for windows application aid. The result of the research shows that (1) human resource competence has positive and significant effect on effectiveness of performance based budgeting, (2) reward, positively and significantly influence to effectiveness of performance budgeting applying, (3) budget utilization have positive and significant influence to effectiveness of application performance-based budgeting.
\end{abstract}

Keywords: Human Resource Competence, Reward, Budget Usage, Performance Based Budget.

\section{PENDAHULUAN}

\subsection{Latar Belakang}

Anggaran berbasis kinerja disusun dengan tujuan untuk mengatasi berbagai kelemahan yang terdapat dalam anggaran tradisional. Penggunaan anggaran berbasis kinerja mampu mengubah arah penggunaan dana dari pemerintah, yang semula berorientasi pada input, tetapi sekarang sudah berorientasi pada output. Pendekatan penganggaran yang berbasis kinerja sangat diperlukan bagi satuan kerja instansi pemerintah yang memberikan pelayanan kepada publik. ( Izzaty, 2012).

Penerapan anggaran berdasarkan kinerja, merupakan bagian tak terpisahkan dalam proses penyempurnaan manajemen keuangan (anggaran Negara), yang bertujuan untuk meningkatkan transparansi dan akuntabilitas pelayanan public serta efektivitas dari pelaksanaan kebijakan dan program. Hal itu bertujuan untuk meningkatkan pelayanan kepada masyarakat, yang berkaitan dengan kebijakan, perencanaan, penganggaran, dan pelaksanaanya. Untuk mengatasi kelemahan dalam penganggaran dan pengelolaan keuangan, diperlukan penyempurnaan pada landasan konstitusional mengenai pengelolaan anggaran Negara, perbaikan system penyusunan anggaran, pengelolaan yang transparan dan akuntabilitas hingga peningkatan kualitas sumber daya manusia (Nawastri, 2015). Pendekatan penganggaran yang berbasis kinerja sangat diperlukan bagi satuan kerja instansi pemerintah yang memberikan pelayanan kepada publik. Selain itu di Indonesia, pelaksanaan anggaran berbasis kinerja pada dasarnya didukung beberapa kebijakan seperti UndangUndang (UU) No. 32 Tahun 2004 tentang Pemerintah Daerah, UU No. 33 Tahun 2005 Tentang Perimbangan Keuangan Antara Pemerintah Pusat dan Daerah. Berbagai UndangUndang tersebut berfungsi sebagai dasar anggaran berbasis kinerja yang mengharuskan 
pemerintah melakukan reformasi di segala bidang termasuk didalamnya perubahan system anggaran keuangan daerah yang lebih berpihak pada kepentingan publik (Mappaiwang, 2013).

Hal yang paling penting dalam menghadapi implementasi perubahan system penganggaran adalah permasalahan kesiapan SDM. SDM harus terus dibenahi sehingga selalu siap menghadapi perubahan khususnya dalam proses penganggaran dalam rangka peningkatan kinerja instansi pemerintah. Peningkatan kompetensi dibidang penganggaran juga dapat dilaksanakan secara terkoordinasi dalam satu atap sehingga efisien dan efektif (Cholifah, 2013).

SDM merupakan salah satu faktor internal yang memegang peranan penting berhasil tidaknya suatu organisasi dalam mencapai tujuan sehingga perlu diarahkan melalui manajemen sumber daya manusia yang efektif dan efesien. Agar SDM mempunyai etos kerja tinggi, terampil dan terlatih sebuah organisasi dapat melakukan pelatihan, pendidikan, dan bimbingan bagi SDM. Hanya saja untuk menghasilkan kinerja dan prestasi kerja yang tinggi seorang karyawan tidak hanya perlu memiliki keterampilan, tetapi juga harus memiliki keinginan dan kegairahan untuk berprestasi tinggi karena berkembang tidaknya suatu organisasi, sangat ditentukan oleh anggota atau personel dari organisasi itu sendiri

( Nalarreason dkk, 2014). Berdasarkan latar belakang masalah, maka dibuat judul penelitian ini "Pengaruh Kompetensi Sumber Daya Manusia, dan Penggunaan Anggaran Terhadap Efektivitas Penerapan Anggaran Berbasis Kinerja Pada Dinas Perindustrian dan Perdagangan Daerah Provinsi Sulawesi Utara ".

\subsection{Tujuan Penelitian}

Tujuan yang hendak dicapai pada penelitian ini adalah :

1. Untuk mengetahui pengaruh kompetensi sumber daya manusia terhadap efektivitas penerapan Anggaran Berbasis Kinerja pada Dinas Perindustrian dan Perdagangan Daerah Provinsi Sulawesi Utara .

2. Untuk mengetahui pengaruh penggunaan anggaran terhadap efektivitas penerapan Anggaran Berbasis Kinerja pada Dinas Perindustrian dan Perdagangan Daerah Provinsi Sulawesi Utara.

3. Untuk mengetahui secara bersama-sama pengaruh kompetensi sumber daya manusia dan penggunaan anggaran terhadap efektivitas penerapan Anggaran Berbasis Kinerja pada Dinas Perindustrian dan Perdagangan Daerah Provinsi Sulawesi Utara.

\section{TINJAUAN PUSTAKA}

\subsection{Anggaran Berbasis Kinerja}

Anggaran dengan pendekatan kinerja merupakan suatu system anggaran yang mengutamakan upaya pencapaian hasil kerja atau output dari perencanaan alokasi biaya atau input yang ditetapkan. Anggaran kinerja yang efektif lebih dari sebuah objek anggaran program atau organisasi dengan outcome yang telah diantisipasi. Hal ini akan menjelaskan hubungan biaya dengan hasil (result). Sebagai variasi antara perencanaan dan kejadian sebenarnya, manajer dapat menentukan input-input resource dan bagaimana input-input tersebut berhubungan dengan outcome untuk menentukan efektivitas dan efesiensi program (Darise, 2012).

\subsection{Kompetensi Sumber Daya Manusia}

Kompetensi sumber daya manusia mencakup kapasitasnya, yaitu kemampuan seseorang atau individu, suatu organisasi (kelembagan), atau suatu system untuk melaksanakan fungsi-fungsi atau kewenangannya untuk mencapai tujuannya secara efektif dan efesien ( Azhar, 2012). Kapasitas harus dilihat sebagai kemampuan untuk mencapai 
kinerja, untuk menghasilkan keluaran-keluaran (outputs) dan hasil-hasil (outcomes). Untuk menilai kapasitas dan kompetensi sumber daya manusia dalam melaksanakan suatu fungsi, termasuk akuntansi, dan dapat dilihat dari level of responsibility dan kompetensi sumber daya tersebut. Tanggung jawab dapat dilihat dari atau teruang dalam deskripsi jabatan. Deskripsi jabatan merupakan dasar untuk melaksanakan tugas dengan baik. Tanpa adanya deskripsi jabatan yang jelas, sumber daya tersebut tidak dapat melaksanakan tugasnya dengan baik. Sedangkan kompetensi dapat dilihat dari latar belakang pendidikan, pelatihan-pelatihan yang pernah diikuti, dan dari keterampilan yang dinyatakan dalam pelaksanaan tugas.

\subsection{Penggunaan Anggaran}

Pengertian penggunaan anggaran menurut (Nawawi 2012), adalah pencatatan hasil yang dicapai dalam melaksanakan fungsi-fungsi khusus suatu pekerjaan atau kegiatan bekerja selama suatu periode tertentu. Sementara itu, (Mahsun 2013), suatu proses penilaian kemajuan pekerjaan terhadap tujuan dan sasaran yang telah ditentukan sebelumnya, termasuk informasi atas: efisiensi penggunaan sumber daya dalam menghasilakan barang dan jasa; kualitas barang dan jasa (seberapa baik barang dan jasa diserahkan kepada pelanggan dan sampai seberapa jauh pelanggan terpuaskan); hasil kegiatan dibandingkan dengan maksud yang diinginkan dan efektivitas tindakan dalam mencapai tujuan.

\subsection{Hipotesis}

H1= Kompetensi Sumber Daya Manusia berpengaruh terhadap Efektivitas Penerapan Anggaran Berbasis Kinerja.

H2= Penggunaan Anggaran berpengaruh terhadap Efektivitas Penerapan Anggaran Berbasis Kinerja.

H3= Kompetensi Sumber Daya Manusia dan Penggunaan Anggaran berpengaruh terhadap Efektivitas Penerapan Anggaran Berbasis Kinerja.

\subsection{Penelitian Terdahulu}

1. Penelitian yang dilakukan oleh Syarifah Massuki Fitri, dkk (2013) menunjukkan bahwa gaya kepemimpinan berpengaruh negatif dan signifikan terhadap anggaran berbasis kinerja. Kualitas sumber daya dan reward berpengaruh signifikan terhadap anggaran berbasis kinerja. Komitmen organisasi dan punishment tidak berpengaruh terhadap anggaran berbasis kinerja. Secara simultan, gaya kepemimpinan, komitmen seluruh komponen organisasi, kualitas sumber daya, reward, dan punishment berpengaruh positif dan signifikan terhadap anggaran berbasis kinerja pada pemerintahan kabupaten Lombok Barat.

2. Penelitian yang dilakukan Kadek Marlina Nakarreason, dkk (2014) menunjukkan bahwa sumber daya manusia, komitmen organisasi, penghargaan dan sanksi berpengaruh terhadap penerapan anggaran berbasis kinerja. Sementara itu, gaya kepemimpinan tidak berpengaruh terhadap penerapan anggaran berbasis kinerja

3. Penelitian yang dilakukan Pradibta Diastuti (2017) penelitian menunjukkan bahwa sumberdaya manusia, komitmen organisasi, penghargaan dan sanksi berpengaruh terhadap penerapan anggaran berbasis kinerja. Sementara itu, gaya kepemimpinan tidak berpengaruh terhadap penerapan anggaran berbasis kinerja

\section{METODE PENELITIAN}

\subsection{Jenis dan sumber data}

Penelitian ini menggunakan metode deskriptif kuantitatif. Deskriptif merupakan metode penelitian yang digunakan untuk menggambarkan masalah yang terjadi pada masa sekarang atau yang sedang berlangsung, yang bertujuan untuk mendeskripsikan apa yang terjadi sebagaimana mestinya pada saat penelitian dilakukan. Metode deskriptif adalah 
metode yang digunakan untuk menggambarkan atau menganalisis suatu hasil penelitian tetapi tidak digunakan untuk membuat kesimpulan (Sugiyono, 2013:29). Pendekatan kuantitatif adalah pendekatan yang dilakukan dengan cara pencatatan dan penganalisaan data hasil penelitian secara eksak dengan menggunakan perhitungan statistic. Metode kuantitatif data penelitian berupa angka-angka dan analisis menggunakan statistic.Metode kuantitatif digunakan apabila masalah merupakan penyimpangan antara seharusnya dengan yang terjadi, antara aturan dengan pelaksaan, antara teori dengan praktik, antara rencana dengan pelaksanaan (Sugiyono, 2013:23).

\subsection{Populasi Dan Sampel}

Populasi yang dipilih dalam penelitian ini adalah seluruh pegawai Dinas Perindustrian dan Perdagangan Daerah Provinsi Sulawesi Utara. Teknik pengambilan sampel dalam penelitian ini berupa purposive sampling, yaitu pengambian sampel dilakukan hanya atas dasar pertimbangan peneliti saja.

\subsection{Metode Analisis}

Metode yang digunakan untuk menganalisis data instrumen penelitian berupa kuesioner adalah uji kualitas data dengan melakukan uji validitas dan uji reabilitas. Selanjutnya agar hasil perhitungan dapat diinterprestasikan dengan akurat dilakukan uji asumsi klasik yang meliputi uji normalitas, uji multikolonieritas, dan uji heterokedastisitas. Terakhir, dilakukan pengujian terhadap model regresi linear berganda yang meliputi uji koefisien determinasi $\left(\mathrm{R}^{2}\right)$, uji signifikan simultan (uji F), dan Uji t. Semua uji analisis ini dilakukan dengan bantuan software SPSS Statistic versi 23.

\section{HASIL ANALISIS DAN PEMBAHASAN}

\subsection{Hasil Penelitian}

Dalam penelitian ini data yang digunakan adalah data dari hasil penelitian yang diperoleh dari distribusi kuesioner kepada pegawai Dinas Perindustrian dan Perdagangan Daerah Prov Sulut. Dari 75 kuesioner yang didistribusikan, jumlah kuesioner yang dikembalikan hanya 61 kuesioner sehingga jumlah responden pada penelitian ini adalah sebanyak 61 responden.

\section{Uji Kualitas Data}

Untuk melihat apakah data yang diperoleh dari kuesioner yang dibagikan dapat dipercaya dilakukan uji validitas dan uji reliabilitas. Penelitian ini telah lulus uji validitas dan reliabilitas.

\section{Uji Asumsi Klasik}

Agar hasil penelitian dapat diinterprestasikan dengan akurat maka dilakukan uji asumsi klasik. Penelitian ini telah lulus uji normalitas, multikolonieritas serta heteroskedastisitas.

\section{Uji Hipotesis}

\begin{tabular}{|c|r|r|r|r|r|}
\hline & \multicolumn{6}{|c|}{ Model Summary $^{\text {b }}$} \\
Model & $\mathrm{R}$ & R Square & \multicolumn{1}{c|}{$\begin{array}{c}\text { Adjusted R } \\
\text { Square }\end{array}$} & $\begin{array}{c}\text { Std. Error of the } \\
\text { Estimate }\end{array}$ & Durbin-Watson \\
\hline 1 & $.588^{\mathrm{a}}$ & .346 & .324 & 2.67457 & 2.424 \\
\hline
\end{tabular}

a. Predictors: (Constant), Penggunaan_Anggaran, Kompetensi_Sumber_Daya_Manusia

b. Dependent Variable: Efektivitas_Penerapan_Anggaran_Berbasis_Kinerja

Sumber : Hasil Pengelolaan Data Primer Dengan Alat Bantu SPSS versi 23. 
Pada tabel di atas terlihat bahwa koefisien determinasi yang disesuaikan (Adjusted $R$ Square) sebesar 0.324 memberi pengertian bahwa variasi yang terjadi pada variabel Y (Efektivitas Penerapan Anggaran Berbasis Kinerja) adalah 32,4\% ditentukan oleh variabel Kompetensi Sumber Daya Manusia, dan Penggunaan Anggaran dan selebihnya sebesar 67,6 $\%(100 \%-32,4 \%)$.

\section{Uji T}

\begin{tabular}{|c|c|c|c|c|c|}
\hline \multirow[b]{3}{*}{ Model } & \multicolumn{3}{|c|}{ Coefficients $^{a}$} & \multirow[b]{3}{*}{$T$} & \multirow[b]{3}{*}{ Sig. } \\
\hline & \multicolumn{2}{|c|}{$\begin{array}{c}\text { Unstandardized } \\
\text { Coefficients }\end{array}$} & \multirow{2}{*}{$\begin{array}{c}\text { Standardized } \\
\text { Coefficients } \\
\text { Beta } \\
\end{array}$} & & \\
\hline & B & Std. Error & & & \\
\hline (Constant) & 4.426 & 4.028 & & 1.099 & .277 \\
\hline $\begin{array}{c}\text { Kompetensi_Sumber_ } \\
\text { Daya_Manusia }\end{array}$ & .545 & .163 & .386 & 3.348 & .001 \\
\hline $\begin{array}{c}\text { Penggunaan_Anggara } \\
\mathrm{n}\end{array}$ & .247 & .180 & .159 & 1.372 & .017 \\
\hline
\end{tabular}

Sumber : Hasil Pengelolaan Data Primer Dengan Alat Bantu SPSS versi 23.

\section{H1= Kompetensi Sumber Daya Manusia berpengaruh terhadap Efektivitas Penerapan} Anggaran Berbasis Kinerja

Variabel Kompetensi Sumber Daya Manusia $\left(\mathrm{X}_{1}\right)$ mempunyai nilai t hitung sebesar 3,348 dan nilai signifikasi $0,001<0,05$. Dengan nilai $t$ hitung $(3,348)>$ nilai $t$ tabel $(1,099)$, maka Ho ditolak dan Ha diterima.Hal ini membuktikan bahwa Kompetensi Sumber Daya Manusia berpengaruh signifikan terhadap Efektivitas Penerapan Anggaran Berbasis Kinerja.

\section{H2= Penggunaan Anggaran berpengaruh terhadap Efektivitas Penerapan Anggaran Berbasis Kinerja}

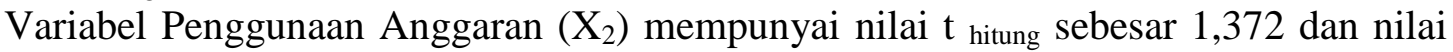
signifikasi $0,017<0,05$. Dengan nilai $t_{\text {hitung }}(1.372)>$ nilai $t_{\text {tabel }}(1,099)$, maka Ho ditolak dan Ha diterima.Hal ini membuktikan bahwa Peggunaan Anggaran berpengaruh signifikan terhadap Efektivitas Penerapan Anggaran Berbasis Kinerja.

Berdasarkan tabel persamaan regresi linear berganda dapat ditulis sebagai berikut:
$\mathrm{Y} \quad$ : Anggaran berbasis kinerja
$\alpha \quad$ : Konstanta
$\mathrm{b}_{1}, \mathrm{~b}_{2}, \quad$ : Koefisen regresi berganda
$\mathrm{X}_{1} \quad$ : Kompetensi sumber daya manusia
$\mathrm{X}_{2} \quad$ : Penggunaan Anggaran
e : Error 
Uji F

ANOVA $^{\mathrm{a}}$

\begin{tabular}{|r|r|r|r|r|r|}
\hline \multicolumn{1}{|c|}{ Model } & Sum of Squares & df & Mean Square & F & Sig. \\
\hline 1 & 219.796 & 2 & 109.898 & 15.363 & $.000^{\mathrm{b}}$ \\
Regression & 414.892 & 58 & 7.153 & & \\
Residual & 634.689 & 60 & & & \\
Total & & & & \\
\hline
\end{tabular}

a. Dependent Variable: Efektivitas_Penerapan_Anggaran_Berbasis_Kinerja

b. Predictors: (Constant), Penggunaan_Anggaran, Kompetensi_Sumber_Daya_Manusia

Sumber : Hasil Pengelolaan Data Primer Dengan Alat Bantu SPSS versi 23.

\section{H4= Kompetensi Sumber Daya Manusia dan Penggunaan Anggaran berpengaruh Efektivitas Penerapan Anggaran Berbasis Kinerja}

Dalam model ANOVA dapat diperoleh $\mathrm{F}$ hitung sebesar 15.363 dengan tingkat signifikan 0,000. Oleh karena tingkat signifikan tersebut lebih kecil dari pada 0,05 maka variabel Kompetensi Sumber Daya Manusia, dan Penggunaan Anggaran secara simultan atau secara bersama-sama berpengaruh terhadap variabel dependen yaitu Efektivitas Penerapan Anggaran Berbasis Kinerja.

\subsection{Pembahasan}

Pengaruh Kompetensi Sumber Daya Manusia Terhadap Efektivitas Penerapan Anggaran Berbasis Kinerja

Hasil pengujian statistik menunjukkan kompetensi sumber daya manusia berpengaruh terhadap efektivitas penerapan anggaran berbasis kinerja.Hal ini dibuktikan oleh hasil uji $t$ yang menunjukkanKompetensi Sumber Daya Manusia $\left(\mathrm{X}_{1}\right)$ mempunyai nilai t hitung sebesar 3,348 dan nilai signifikasi $0,001<0,05$. Dengan nilai $t_{\text {hitung }}(3,348)>$ nilai $t_{\text {tabel }}(1,099)$.

Pengaruh Penggunaan Anggaran Terhadap Efektivitas Penerapan Anggaran Berbasis Kinerja

Hasil pengujian statistik menunjukkan penggunaan anggaran berpengaruh terhadap efektivitas penerapan anggaran berbasis kinerja. Hal ini dibuktikan oleh hasil uji t yang menunjukkan Variabel Penggunaan Anggaran $\left(\mathrm{X}_{2}\right)$ mempunyai nilai $\mathrm{t}_{\text {hitung }}$ sebesar 1,372 dan nilai signifikasi $0,017<0,05$. Dengan nilai $t_{\text {hitung }}(1.372)>$ nilai $t_{\text {tabel }}(1,099)$.

\section{Pengaruh Kompetensi Sumber Daya Manusia dan Penggunaan Anggaran} Terhadap Efektivitas Penerapan Anggaran Berbasis Kinerja

Berdasarkan uji $\mathrm{F}$ dapat dilihat bahwa secara simultan (bersama-sama) variabel Kompetensi Sumber Daya Manusia $\left(\mathrm{X}_{1}\right)$, Penggunaan Anggaran $\left(\mathrm{X}_{2}\right)$ berpengaruh terhadap Efektvitas penerapan anggaran berbasis kinerja.Hal ini dibuktikan $\mathrm{F}$ hitung sebesar 15.363 dengan tingkat signifikan 0,000. Oleh karena tingkat signifikan tersebut lebih kecil dari pada 0,05 maka variabel Kompetensi Sumber Daya Manusia, dan Penggunaan Anggaran secara simultan atau secara bersama-sama berpengaruh terhadap variabel dependen yaitu Efektivitas Penerapan Anggaran Berbasis Kinerja.

\section{KESIMPULAN DAN SARAN}

\subsection{Kesimpulan}

Berdasarkan hasil penelitian dan setelah di adakan pengujian hipotesis terhadap permasalahan yang telah dikemukakan, maka kesimpulan yang dapat diambil adalah sebagai berikut. 
1. Secara parsial Kompetensi sumber daya manusia berpengaruh positif dan signifikan terhadap efektivitas penerapan anggaran berbasis kirerja pada Dinas Perindustrian dan Perdagangan Daerah Prov Sulut. Hal ini dibuktikan olehh hasil uji t yang

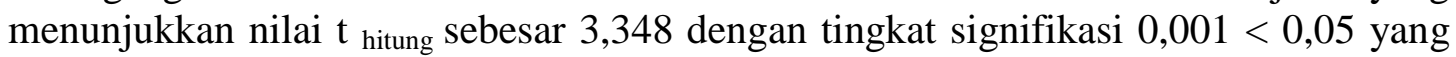
mengidentifikasikan bahwa variabel $X_{1}$ (Kompetensi Sumber Daya Manusia) berpengaruh secara positif dan signifikan terhadap variabel Y (Efektivitas penerapan anggaran berbasis kinerja ).

2. Secara Parsial Penggunaan Anggaran berpengaruh positif dan signifikan terhadap efektivitas penerapananggaran berbasis kinerja. Hal ini dibuktikan oleh hasil uji $t$ yang menunjukkan nilai $t$ hitung sebesar 1,372 dengan tingkat signifikan $0,017<0,05$ yang mengidentifikasikan bahwa variabel $\mathrm{X}_{3}$ (Penggunaan Anggaran) berpengaruh secara positif dan signifikan terhadap variabel Y (Efektivitas penerapan anggaran berbasis kinerja ).

3. Secara simultan (bersama-sama) variable Kompetensi Sumber Daya Manusia $\left(\mathrm{X}_{1}\right)$ dan Penggunaan Anggaran $\left(\mathrm{X}_{2}\right)$, berpengaruh secara positif dan signifikan terhadap Efektvitas penerapan anggaran berbasis kinerja. Hal ini dibuktikan $\mathrm{F}$ hitung sebesar 15.363 dengan tingkat signifikan 0,000. Oleh karena tingkat signifikan tersebut lebih kecil daripada 0,05

\subsection{Saran}

Saran-saran yang dapat diberikan penulis berdasarkan hasil penelitian yang telah dilakukan adalah sebagai berikut.

1. Bagi Dinas Perdangangandan Perindustrian Daerah Prov Sulut, dengan tingginya pengaruh kompetensi sumber daya manusia terhadap efektivitas penerapan anggaran berbasis kinerja, maka diharapkan untuk dapat mempertahankan, bahkan meningkatkan kompetensi sumber daya manusia yang membawa pengaruh positif terhadap efektivitas penerapananggaran berbasis kinerja.

2. Dengan tingginya pengaruh penggunaan anggaran terhadap efektivitas penerapan anggaran berbasis kinerja, maka diharapkan untuk dapat mempertahankan, bahkan meningkatkan penggunaan anggaran yang efektif yang membawa pengaruh positif terhadap efektivitas penerapan anggaran berbasis kinerja.

3. Tetap meningkatkan dan mempertahankan kompetensi sumber daya manusia dan penggunaan anggaran dengan beberapa cara yang dapat dilakukan umtuk meningktakan dan mempertahankan antara lain dengan mengutamakan upaya pencapaian hasil kerja atau output yang maksimal, melibatkan seluruh jajaran dalam proses perencanaan, menghasilkan program yang sesuai dengan visi-misi organisasi, dan berusaha menghasilkan pelayanan public yang lebih baik.

\section{DAFTAR PUSTAKA}

Arsyad Azhar, 2012. Media Pembelajaran cetakan ke-15.Jakarta: Rajawalli Pers.

Cholifah, 2013. Rancangan Model Efektivitas Penggunaan Anggaran Berbasis Kinerja Dinas Pendapatan Daerah Prov Jawa Timur. Jurnal WIGA Vol. 3 No. 2, September 2013 ISSN NO 2088-0944.

Darise, Nurlan. 2012. Akuntansi Keuangan Daerah, penerbit indeks, Jakarta.

Diastuti Pradibta, 2017. Analisis Faktor - Faktor Yang Mempengaruhi Penerapan Anggaran Berbasis Kinerja Organisasi Perangkat Daerah Kabupaten Boyolali. Skipsi Fakultas Ekonomi dan Bisnis Universitas Muhammadiyah Surakarta.

Ghozali Imam, 2012. Aplikasi Analisis Multivariate dengan Program SPSS, Edisi Kelima, Badan Penerbit Universitas Diponegoro, Semarang

Herlianto Didit, 2015. Anggaran Keuangan. Gosyen Publishing, Yogyakarta. 
Izzaty, Khairina Nur. 2011. Pengaruh Gaya Kepemimpinan Dan Kualitas Sumber Daya Manusia Terhadap Penerapan Anggaran Berbasis Kinerja Badan Layanan Umum Studi pada BLU. Universitas Diponegoro Semarang). Skripsi.Fakultas Ekonomi. Universitas Diponegoro Semarang.

Mahsun, Mohamad, 2013. Pengukuran Kinerja Sektor Publik, Penerbit BPFE, Yogyakarta.

Mappaiwang, A, dkk,. 2013. Pelaksanaan Anggaran Berbasis Kinerja Pada Dinas Ciptra Karya Dan Tata Ruang Kabupaten Sidenreng Rappang. Fakultas Ilmu Sosial dan Ilmu Politik.Universitas Hasanuddin.

Massuki, Fitri Syarifah, Unti Ludigdo, dan Ali Djamhuri. 2013. Pengaruh Gaya Kepemimpinan, Komitmen, Organisasi, Kualitas Sumber Daya, Reward, Dan Punishment Terhadap Anggaran Berbasis Kinerja (Studi Empirik Pada Pemerintah Kabupaten Lombok Barat). Jurnal Dinamika Akuntansi Vol. 5,No. 2, September 2013, pp. 157-171

Nawawi, Hadari. (2012). Evaluasi dan manajemen kinerja di lingkungan perusahaan dan industri. Yogyakarta: Gadjah Mada University Press.

Sugiyono.2013, Metode Penelitian Bisnis, Penerbit Alfabeta Bandung.

Undang-Undang Nomor 32 Tahun 1999 Tentang Pemerintahan Daerah. Peraturan Pemerintah dan Pertanggung jawaban Keuangan Daerah. 